\title{
Non-destructive Magnetic Evaluation of Ground Surfaces Made of Bearing Steel of Variable Hardness
}

Zuzana Durstová, Branislav Mičieta, Mária Čilliková, Miroslav Neslušan, Jozef Mrázik Faculty of Mechanical Engineering, University of Žilina, Univerzitná 8215/1, 01026 Žilina, Slovak Republic; E-mail: zuzana.durstova@fstroj.uniza.sk, branislav.micieta@fstroj.uniza.sk,maria.cillikova@fstroj.uniza.sk, miroslav.neslusan@fstroj.uniza.sk, jozef.mrazik@fstroj.uniza.sk

This paper deals with non destructive magnetic evaluation of ground surfaces of variable hardness based on Barkhausen noise (BN) technique. Except magnetic investigation, obtained BN signals are correlated with metallographic observation, microhardness readings as well as residual stress measurements. The results show that regime of heat treatment - annealing after hardening significantly affects the possible concept for monitoring surfaces after grinding. Conventionally heat treated surfaces of hardness $62 \mathrm{HRC}$ indicate the typical surface thermal softening induced by grinding cycle whereas samples of lower hardness exhibit rehardening effect associated with the progressive decrease of Barkhausen noise responses along with the developed grinding wheel wear.

Keywords: Heat treatment, grinding, Barkhausen noise

\section{Acknowledgement}

The authors gratefully acknowledge the support by KEGA agency (project $n .005 \check{Z} U$ 4/2014).

\section{References}

[1] MOORTHY, V., et. all.(2001). Evaluation of heat treatment and deformation induced changes in material properties in gear steels using magnetic Barkhausen noise analysis, Conference ICBN 03, Tampere.

[2] ČILLIKOVÁ, M., MIČÚCH, M., NESLUŠAN, M., MIČIETOVÁ, A. (2013). Nondestructrive micromagnetic evaluation of surface damage after grinding, In: Manufacturing technology,Vol.13, No. 2, pp. 152 - 157.

[3] KAMEDA, J., RANJAN, R. (1987) Nondestructive evaluation of steels using acoustic and magnetic Barkhausen signals - II. Effect of intergranular impurity segregation, In: Acta Metall. 35/7, pp. 1527 - 1531.

[4] BUTTLE, D.J., SCRUBY, C.B., JAKUBOVICS, J.P., BRIGGS, G.A.D. (1991). Magneto-acoustic and Barkhausen emission: their dependence on dislocations in iron, In: NDTE Int. 24, pp. $47-54$.

[5] GATELIER-ROTHEA, C., CHICOIS, J., FOUGERES, R., FLEISCHMANN, P. (1998). Characterization of pure iron and carbon-iron binary alloy by Barkhausen noise measurements: study of the influence of stress and microstructure, In: Acta Mater. 46/14, pp. 4873 - 4882.

[6] RANJAN, R., JILES, D. C., RASTOGI, P., (1987). Magnetic properties of decarburized steels: An investigation of the effects of grain size and carbon content, In: IEEE Trans. Magn. 23/3, pp. $1869-1876$.

[7] MOORTHY, V., VAIDYANATHAN, S., JAYAKUMAR, T., RAJ, B., (1998). On the influence of tempered microstructures on magnetic Barkhausen emission in ferritic steels, In: Philos. Mag. A 77/6, pp.1499- 1514.

[8] ČILLIKOVÁ M., NESLUŠAN, M., KOLAŘíK, K., MIČÚCH, M., (2014). Detection of Surface Damage after Grinding of Large Case-hardened Bearing Rings, In: Engineering Materials, Vol. 581, pp $205-210$.

[9] KARPUCHEWSKI, B., (2002). Introduction to micro magnetic techniques, ICBN 01 Hannover, Germany. 